\title{
MYSTICISM IN BATIK INDUSTRIAL RELATION The Study of Trust Achievement on the Survivability of Small-Medium Batik Industry at Pekalongan City ${ }^{1}$

\author{
Imam Kanafi and Susminingsih \\ STAIN Kudus - Indonesia
}

\begin{abstract}
Relationship between economy and religion had been known for long time ago as it was found in Max Weber's books "The Protestant Ethic and The Spirit of Capitalism" and "The Protestant Sects and The Spirit of Capitalism". This paper examines the extent to which mysticism practices have been conducted among the employers and employees of Batik Industries in Pekalongan City. It argues that mysticism has an important role to reinforce the social capital and make the industry survive, especially to face many problems related to productivity, motivation, trust as well as wage issues. By practicing mystics and religious traditions, like dhikiran, manakiban, bawl and muludan, people have spiritual force which has an important role both for personally and professionally in the work place, especially to maintain the relationship between employees and employers. Also they could be stronger when faced the changes and challenges of business and their industry can survive.
\end{abstract}

Keywords: Batik industry, mysticism, trust achievement, symbolic interactionism.

\section{Introduction}

Wherever people live is always influenced by the dynamics of the growing trade at that time. Reciprocation of a society depends on the trade aspect as well as the existence of the city of Pekalongan batik.

1 The earlier version of this paper was presented at The $12^{\text {th }}$ Annual International Conference on Islamic Studies (AICIS), held by the Ministry of Religious Affairs and the State Institute of Islamic Studies (IAIN) Sunan Ampel, Surabaya, 5-8 November 2012. 
The region of Pekalongan is located on the western side of the North Coast of Central Java Province. The city of Pekalongan is divided into four districts: North Pekalongan (9 sub-districts), South Pekalongan (11 sub-districts), West Pekalongan (13 sub-districts) and East Pekalongan (13 sub-districts). As of 2011, the population of this city was around 315,368 -mostly Islam in religion (95\%). The city of Pekalongan supported with seaport and two land transportation modes that is the North Coast Road and North Java Railway that connect Merak and Banyuwangi on the Northern beach of Java. These port, road and railway facilitate intercity and interisland transportation and eventually influence commercial and economic development of this city and neighboring areas. So, Pekalongan grows as commercial city where people come and go to do business. One of the best-selling commodities of this city is batik products which traditionally are produced as home industry by hundreds of small and medium enterprises (SMEs) rather than by a handful of large enterprises (LE).

Relation between economy and religion had been known for a long time ago, as Max Weber wrote in his books, namely Die Protestantische Ethic und der Geist des Kapitalismus (The Protestant Ethic and The Spirit of Capitalism) and Die Protestantische Sects und der Geist des Kapitalismus (The Protestant Sects and The Spirit of Capitalism). Collaboration between spiritual development and wealth becomes a unique chemistry; the act which doing in meditation and meditation which happen in the act. ${ }^{2}$ This is important to note that spiritual well being actually has important role by four domains like what Fisher said, personal, communal, environmental and transcendental. ${ }^{3}$ One's mystically experiences ${ }^{4}$ when he tries to learn transcendent thing, can raise senses like happiness and calmness.

How about the mysticism? It is defined as love to God and different from asceticism because it has the strength of love. This love can make someone able to receive, enjoy all what have God gives to

\footnotetext{
${ }^{2}$ S. Hasan, Sufism and The Spirit of Capitalism (Malang: UIN Malang Press, 2009), p. 26.

${ }^{3}$ M. Fernando, et.al., "The Relationship Between Spiritual Well-Being and Ethical Orientations in Decision Making: An Empirical Study with Business Executives in Australia," Journal of Business Ethics, DOI 10.1007/s10551-009-0355-y (2010).

${ }^{4}$ Romdon, Tashawuf dan Aliran Kebatinan: Suatu Perbandingan antara Aspek-Aspek Mistik. Islam dengan Aspek-Aspek Mistik Jawa (Yogyakarta: LESFI, 1995), p. 8.
} 
them. ${ }^{5}$ By local context, mysticism is something that produced by a process of constructing of culturing religion at Java. ${ }^{6}$

It is very interesting to analyse the mysticism experiences in industrial relation, especially to know how the spiritual capability (as output from one's mystic experience) can decide employer and employee interaction. Ritual action and belief are alike to be understood as forms of symbolic statement about social order. ${ }^{7}$ In batik industry, it has an important role to reinforce their social capital and make the industry more survive especially to face many problems for example about productivity, motivation, trust and also wage as physically thing. ${ }^{8}$ Another component likes culture, family system, organization even religion or trust, also have close relation in this matter. ${ }^{9}$ So we know that one's thought can be influenced by religion concept and his experiences which for Javanese totally and not be separated between material and non material. For batik industry society at Pekalongan, the spiritual experience is very interesting to analyse because they have the important role in economic sector, ${ }^{10}$ strongly doing their religion tradition and high spirit to do their work.

5 See A. Schimmel, Mystical Dimension of Islam, trans. Sapardi Djoko et.al. (Jakarta: Pustaka Firdaus, 1975), p. 2. About mysticism and spirituality see T. Wayne, The Mystic Heart: Discovering a Universal Spirituality in The World's Religions (Canada: Publishers Group West, 2001).

${ }^{6}$ M. Damami, Makna Agama Dalam Masyarakat Jawa (Yogyakarta: LESFI, 2002), p. 101.

${ }^{7}$ See R. Needham, Belief, Language, and Experience (Oxford: Basil Blackwell \& Mott Ltd, 1972).

${ }^{8}$ Regarding to incentive system can be found easily at small and medium industries. See S. Kaplan and R. Henderson, "Inertia and Incentives: Bridging Organizational Economics and Organizational Theory" Organization Science, Vol. 16, No. 5 (2005): pp. 509-521.

${ }^{9}$ M. C. Vallejo, "A Model to Study the Organizational Culture of The Family Firm," Small Business Economy, 36 (2011): pp. 47-64; B.V. Bjerke, "A Typified, Cultured Based, Interpretation of Management of SMEs in Southeast Asia," Asia Pasific Journal of Management, Vol. 17 (2000): pp. 103-132. Regarding to social construction in organization of Berger and Luckman (1967) see J.W. Meyer and B. Rowan, "Institutionalized Organizations: Formal Structure as Myth \& Ceremony," The American Journal of Sociology, Vol. 83, No. 2 (1977): pp. 340-363. About shared values in such community see Mc W. Andrew, "Some immaterial aspects of community economies in eastern Indonesia." The Australian Journal of Anthropology, Vol. 20, No.2 (2009): pp. 163-177.

10 S. K. Widodo, Ikan Layang Terbang Menjulang, Perkembangan Pelabuban Pekalongan Menjadi Pelabuhan Perikanan 1990-1990 (Semarang: Badan Penerbit UNDIP \& Toyota Foundation, 2005). 
Batik process is not only to draw the color and motive on the cloth, but also many aspects involved in batik process. The motif and color actually as manifestation from human desire to their God, human relationship and with their environment. Because of this, from batik we can see about the people culture development. It's easy to learn, that in all human behavior, it can't be separated from the symbols, because man as animal symbolicum. The symbolic thinking and symbolic behavior are specific humanity. From this, a man does the construct of culture reality as symbolization of their life.

Until now, batik as art remains easily found at many places in Indonesia, especially in Pekalongan City. It is evidence that there is a high survivability of employer-employee in batik industry. This paper assumes that one of survivability factor is the relationship between employer and employee that not only consists of transactional relation, but also social relation, which based on spiritual consciousness, and then raises the trust achievement for each other. In Pekalongan City, there are many tradition which done by employer-employee, namely dhikiran (worship program by calling the names of Allah and the kind words, to remember and feel the presence of God), manakiban (a special program organized to do the reading the biography of a figure who can serve as role models in worship to God, such as the biography of Sheikh Abdul Qadir al-Jilani), haw (event held specifically to commemorate the day of the death of a leading figure that has an important role for the spread of Islam) and muludan (religious activities were held to commemorate the birth of the prophet Muhammad, with the reading of the biography of the prophet, praise upon personal dignity, and a reminder of the ideals that should be practiced in the face of life.).

\section{Batik Pekalongan as a Symbol and a Commodity}

The word of batik, is genuine of Java language, it consists of two syllables "amba" and "tik". "Amba" literally means to write and "tik" or "titik" means the dropping of some agents on clothes which is being dyed. This agent we know now is wax, which by covering part of the surface, produces of itself certain designs. Even though this technique has been done in other parts in the world such as in Africa, China and Japan, batik is well-known as an icon of Indonesia in international forum particularly after UNESCO recognition on October, 2 2009 that batik is genuine and intangible culture heritage of Indonesia. There are three main regions of batik production in Indonesia, namely 
Central Java, South-West Java and the North Coast of Java. Each region of batik production represents its own regional identity because of its differences in style and motif, including Pekalongan, as a leading production center of pesisir (coastal) batik in Indonesia.

Firstly, batik is not a commercial thing. Only special people can use batik, like cleric. The king received patola, the expensive cloth from India or from Thailand. Because of this, astacandala (the title for a group of people who have the expertise to make the batik cloth in the ancient Javanese) make the same cloth but with other different technic, with batik process. Since that, batik production grows up in Pekalongan, and almost $70 \%$ of Indonesian batiks are produced in Pekalongan. The data 2009 indicate that in Pekalongan region there are at least 6000 business units that actively produced batik cloth in various motifs and designs.

The batik Pekalongan entered a gloomy period in the 1970s following the special treatment from the Old Order administration of this country. In 1980s and 1990s with the emergence of batik prints which are fine looking and inexpensive, batik industry in Pekalongan started to decline and revived in 2000s when UNESCO declared that batik is the intangible cultural heritage of Indonesia. The newest, at Pekalongan City on 3rd-7th October 2012 we had the National Batik Week which very useful to promote batik product, and especially on this moment, all member of participant must use the batik cloth which processed by tulis (write) and cap (stamp) techniques.

So, batik as a symbol describes the relation between human esoteric dimension, containing the values and belief systems about the essence of the reality of life in the universe, with the phenomenon of human life on the exoteric dimension. The diversity of people's belief and the changes that continue to take place due to cultural influences from a variety of traditions, the symbols are actualized in diversified and grown. The development of various models of batik in Pekalongan shows the symbolic interaction between beliefs and traditions that grown as a response to the social, cultural and economic interests faced by the community.

Batik as a commodity shows to everyone that the mind processing influences the survivability of batik industry, especially for employer and employee. In this context, batik is used as a trade commodity that in practice applies the law of the market economy. 


\section{Symbolic Interactionism Theory}

The existence of many symbols in society builds the symbol system and becomes a culture essential. The symbolic interactionism theory applies and tries to explain the human behavior related to the meaning of thing. Blumer's symbolic interactionism theory came up with three reasons regarding this: first, human do something based on the meaning of thing, which gives to them. ${ }^{11}$ Second, the meaning of things rises from social interaction between one and another. Third, the meaning has to be modified through the interpretation process by the people to face the many things.

Symbolic interaction focuses on interpretation over subjective meaning derived from interaction of people with the others of his or her environment. As stated clearly in its name, symbolic interaction emphasizes a close relationship between symbol and interaction. These exchanges produce special meanings and interpretations, unique for each person involved. Symbolic is derived from the word 'symbol' which means signs resulted from consensus. Symbolic interaction tried to understand meaning process and subject defined by employing participant observation to watch carefully how subjects define themselves and their actions respectfully, based on definitions and meanings given by others in their environment.

The symbolic interaction perspective, also called symbolic interactionism, is a major framework of sociological theory. This perspective relies on the symbolic meaning that people develop and rely upon in the process of social interaction. Although symbolic interactionism traces its origins to Max Weber's assertion that individuals act according to their interpretation of the meaning of the world, the American philosopher George Herbert Mead introduced this perspective to American sociology in the 1920s.

Symbolic interaction theory analyzes society by addressing the subjective meanings that people impose on objects, events, and behaviors. Subjective meanings are given primacy because it is believe that people behave based on what they believe and not just on what is objectively true. Thus, society is thought to be socially constructed through human interpretation. People interpret one another's behavior

11 Herbert Blumer, Symbolic Interactionism Perspective and Method (New Jersey: PrenticeHall, Inc., 1969). 
and it forms the social bond. These interpretations are called the "definition of the situation."

A symbol will have no meaning without involving subjects who understand and interpret these symbols. So the meaning of a symbol should always involve some element of the sign, the subject, the situation and meaning, as the figure below:

Figure 1: The meaning of symbol and factors

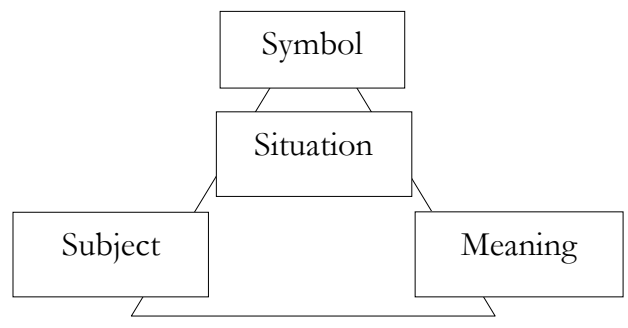

Human life cannot be separated from his relationship with nature and its laws as well as with the Creator. That is why the principles should be kept in mind are the principle of nature as well as the principles of human nature, nationalism, freedom, and cultural principles. By understanding the nature of nature, man should be able to meet all the needs of life both physically and spiritually. It is clear that in some cultures, such as Java; there should always be a balance between conscience that interact with nature and the Creator, based on reason arising from the intellectual and spiritual enlightenment. The conscience of human spiritual and intellectual, connected to the Creator, as the source of all reality. Thus, all three are always in touch with the close and inseparable in the life of the Javanese. All human activity should always seek equilibrium between humans and nature, as well as seeking perfection of life to achieve authentic happiness.

According to Blumer, human group life is a vast process of such defining to others what to do and of interpreting their definition; through this process people come to fit their activities to one another and to form their own individual conduct. Both joint activity and individual conduct are formed in and through this ongoing process. By virtue of symbolic interaction, human group life is necessarily a 
formative process and not a mere arena for the expression of preexiting factors. ${ }^{12}$

\section{Business Model and Relationship in Batik Industry}

Business model in batik industry is done by order system or we call sanggan. The entrepreneur is as the owner of sanggan. Some of them are out of Pekalongan city such as in Bali, Jakarta, Sumatra and many other cities. When they give the order to other employers, it called mbabarke, so the next industry only becomes a worker, and then this order gives to next second employer, until to the next worker. By this order or sanggan system, the worker then puts out the order to their home. It is the reason why we can easily find this work at many places of Pekalongan City. The order or sanggan system in batik industry has different implications for employer and for employee.

For the employers or entrepreneurs, although they do not take a marketing risk, they still take a cost product even wage. By that risk, the employer always wants to get a cheap wage and cheap modals. For the employer or jragan sanggan, order system doesn not have a risk in marketing aspect, but actually has a bigger risk in survivability of industry itself. The bankrupt will easily happens if the owner does not give order or sanggan anymore, and it can influence wage of the employee.

\section{Mystic Tradition at Pekalongan}

The people at Pekalongan bring their life by the norms of Java like a patient and willingness to receive all the condition. Interdependency between value or norm and the mode of thought shows the strong integrity relation between industry and the people at Java Island. In the Javanese world view, humans should strive to harmonize the inner aspect derived from a complex belief system, with the tangible aspects of the behavior of the real action in response to the various problems of life. Thus, sacred belief in the power of the supernatural has a very important role in the behavior of the system and the culture of the people of Java.

The strength of the Javanese community closely adhere to inner beliefs, scientists often refer to these people as the Javanese mystic. What is described as mystical here, is a general sense, the things that a person's beliefs regarding to the existence of supernatural forces,

12 Ibid., p. 10 
which influential to life in the universe. To gain power, one must perform a special ceremony to preserve the connection between humans and the supernatural. Many scholars called it as magic. ${ }^{13}$

Figure 2: Business Model of Batik Industry in Pekalongan

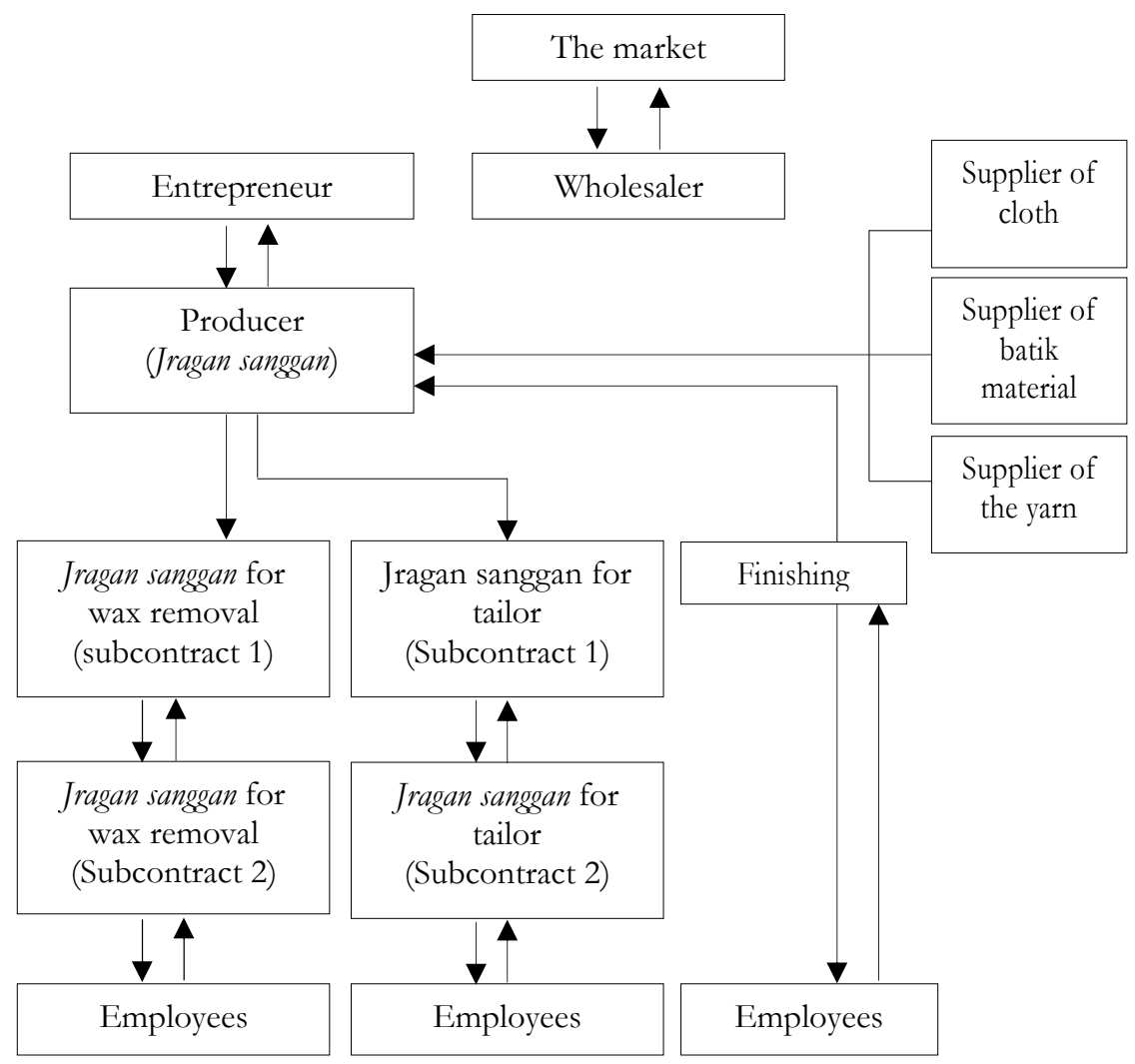

To study about interaction between people and mystic tradition, we must to know that there are 2 types of mystic, white mystic (which based on process and practice just only for kindness and not be a violation of religion) and black mystic (which based on a process and practice with in damage element that can be a violation to religion).

${ }^{13}$ John Skorupski, Symbol and Theory (London: Cambridge University Press, n.d.), pp. 116-9. 
About this its knowing that beliefs as ritual presuppose the necessary existence of such beings are called magical. ${ }^{14}$

It is similar with Sufism movement, who try to make a harmony relation between two aspects, spirituality development and material achievement. ${ }^{15}$ The massage from that harmony relation is the man actually can manage about his desire. ${ }^{16}$ The spiritual implication toward physical aspect saw that spiritual as a source for physical acting. ${ }^{17}$ The equilibrium between spiritual and physical can be Felt by someone when he closes to God. Integrity reaches to God can be found into mystical way. ${ }^{18}$

\section{Dhikiran (Remembering to God)}

This tradition does once a month by tareqah organization (for example Qadiriyah Naqsabandiyah). The procession opened by al Fatihah, then tawasulan or greeting the salawat for one's who have karamah, after that we will hear a prayer from the holy Qur'an and al asmä' al husna (the names of Allah). This tradition also done by each people as what he wants.

Practically there are such conditions that someone has a reason to do it, like purified body (wudu), praying, close the mind, beg the pardon (istighfar) for himself or his teacher and then this tradition closed by the prayer ilähi anta maqsüdi wa ridäka matlübi (three times). Dhikir itself has closed relation to the concept of muräabah. muraqabah derived from one name of God, al-Räqib that Qur'an mentions (4:1) and (30:52). The people do not only remember their God always sees them, but also they must keep their feel from bad thing. ${ }^{19}$ Schimmel said that dhikir is the same with spiritual practices to meet God and bring the good result for people psychology. ${ }^{20}$

\footnotetext{
${ }^{14}$ Needham, Belief, Languange and Experience.

${ }^{15}$ Hasan, Sufism and The Spirit of Capitalism, p. 26.

${ }^{16}$ Suwardi Endraswara, Falsafah Hidup Jawa (Yogyakarta: Cakrawala, 2010), p. 73.

${ }^{17}$ R. Subagya, Kepercayaan dan Agama (Yogyakarta: Kanisius, 1976), p. 15.

18 Mark R. Woodward, Islam in Java: Normative and Mysticism, trans. Hairus Salim (Yogyakarta: LKiS, 1999), p. 6.

${ }^{19}$ See also S. Mulyati, Peran Edukasi Tarekat Qadiriyah Naqsyabandiyyah (Jakarta: Kencana Prenada Media Group, 2010), p. 108.

${ }^{20}$ Schimmel, Mystical Dimension of Islam, p. 218.
} 


\section{Manakiban}

This tradition is done by spiritual organization such as tariqab; Qádiriyah, Naqsabandiyah, Shadhiliah once a week. However manakiban also practiced once a month by a bigger one which consists of many smaller organizations. The goal of this tradition is to remember the biography of the struggle of each the head of spiritual leader. Their lessons had expected to motivate all the people especially for the employer at Pekalongan City.

One of the highly respected spiritual leader and recognized the greatness of his miracles, was Sheikh Abdul Qadir al-Jilani. He is the greatest Sufi master in the history of Islam, his teachings and the influences spread across most of the Muslim world. Even his spiritual level is recognized by the jin in the supernatural realm. His adherence levels and proximity to Allāh, making God granted his request and his prayers. The time after that, his teachings and the advices can be answered prayers for all media requests and his business.

In the tradition of the people in Pekalongan, reading his biography, which is known as manakiban, made by many people to start their business activities in order to gain great success. In fact, there is a tradition that specializes in reading manakib Sheikh Abdul Qadir alJilani, for the purpose of obtaining wealth from the supernatural realm ruled by "The Queens supernatural figure" known as the Den Ayu Dewi Lanjar. Special ritual carried out by combining the traditions of manakib Islam and this animistic tradition, frequent seekers of wealth without going to work hard in accordance with natural laws. Manakiban conducted for this purpose, known by the public Pekalongan as "Manakib Jos".

\section{Hawl}

People do this tradition at Habib Ahmad resting place, at Sapuro, Pekalongan City on Sha bān. About 5. 000 people come to see and practice this havol. Habib Ahmad bin Abdullāh bin Tạalib al Ațas or Habib Hasan is a famous man. He was born on $1255 \mathrm{H}$ at Hajeriem, Hadramaut. He came into Indonesia on 1295-1300 H. When he lived at Pekalongan he built the first school of Salafiyah Ibtidaiyah (Traditional Elementary School), and he died on 24 Rajab $1347 \mathrm{H}$. The process of hawl consists of tablil, salawah, biography of Habib Ahmad, the speech from Habib Ahmad family; Habib Bakir, the head of region, and after that the people would have the advices from them to make better life. 


\section{Muludan}

This tradition is held to celebrate Muhammad saw birthday on Rabiul Awwal, at Kanzus Sholawat, by Habib Lutfi bin Yahya arranged. The word of mawlid or milad in Arabic means birth. The people do this tradition by read together salawat and biography of Muhammad which wrote in Barzanji atau Diba. Similar with hawl, the process of muludan, salawah, tablil and other verses of The Holy Qur'an, the speech of the government even ministry, tawsiyah or advices, the last all the people eat kebuli (rice with meal of goat) together. By this time, the people also bring the mineral water that they hope to get barakab (blessing) for their work. Many Javanese, Egyptian and Chinese came into Kanz alSalawat. By those, people believe that Habib Lutfi had karamah and they want to reach it for their success. For Javanese, karamah is a competencies which reached by religious achievement. They have the power to give and help the other people about the world and the religion. ${ }^{21}$ All of rituals are public events that engage the people at Pekalongan in celebration as social solidarity to renewal of their spiritual force.

In addition, in Pekalongan there is a belief in the mystical power of authority figures sourced from the south coast of the island of Java, known as Nyi Roro Kidul. Mystical strength used by many people to seek wealth ("pesugihan") in an easy waywithout hard work. Belief in these mystical powers could encourage companies to be more motivated and work more with certain rules.

\section{Mysticism as Trust Achievement for Batik Industry}

Batik employers consider that the uncertainty or bankrupt may be happen anytime, so they must have any strategies to avoid it. Sometimes they feel that they need not only capital strength but also spiritual one. It is very useful for them, especially when they face deception from other. Even they have a consciousness that a satisfaction consists of financial and non-financial matters equally. They also belief that trust in business become important thing to face a business change and to their friends. For example, when the market gets into up and down, of course it makes them sad, but it's not happen in a long time. By their business system, an employer can help to lend the white cloth (mori) or dye to coloring to other relation, and

${ }^{21}$ See also Woodward, Islam in Java, p. 251. 
their work will be awake. Interdependent relation between people who involved in batik industry shows the reciprocal concept. But it is trust requirement as what Behnia said that someone will be ready to take a risk and to be trust that someone else will be cooperative too. Now it's interrelating with the concept of belief that it is not only applicable with authority to us, but with confidence to other. ${ }^{22}$

In spite of the business they hold, the employer-employee also improved their religiosity by joint many practices as their prayer or tradition. Of course this research involved belief system theory which look the personality structure as organizationally of belief, behavior and the value which concern on oneself and other self. Ritual action and belief are alike to be understood as forms of symbolic statement about social order. ${ }^{23}$ So we find that human behavior as the product of such factors, economy, culture, belief and many else. By symbolic interactionism perspective, its show to us clearly that when employeremployee have the work meaning as a pray and they always try to interrelate their business with their spirituality. ${ }^{24}$

All rituals that people do produce magical mentality. ${ }^{25}$ For Javanese, that mentality can be reach by what we call tirakat. Tirakat resulting something like irrationality power. That power called irrational because it is not resulted from real of one's effort. ${ }^{26} \mathrm{~A}$ relation between mystic and industrial relation based on assumption that life experiences focus on equilibrium. Business phenomena like up and down makes the anthrop cosmic homology of state of mind which means self-adopting with man-world norm. By this mind, one doesn't fully able to change the condition. Then, it could be rise a consciousness that someone can't work by himself alone but he must be cooperate with others. ${ }^{27}$

The consciousness of Javanese ethics is that human as microcosmic must have good attitude because it influences the macrocosmic. Spirituality has been linked to ethical cognitions and is

\footnotetext{
22 Needham, Belief, Languange and Experience.

23 See Ibid.

${ }^{24}$ See also Blumer, Symbolic Interactionism Perspective.

${ }^{25}$ M. Eliade, Images and Symboles (Kansas City: Sheed Andrews and McMeel, Inc., 1952), p. 112.

${ }^{26}$ Damami, Makna Agama Dalam Masyarakat Jawa, pp. 22-23.

27 Ibid., p. 20.
} 
an important factor determining how individuals perceive the ethically of a situation. It is motivate the Javanese philosophy of life that the life is cycle not be linier. The cycle understanding also motivates the Javanese to do a good thing, and then they will receive a good thing too. ${ }^{28}$ That spirit mentality makes one be calm to face all what happen in his business. Patient also had been an implication for mystic expert, because patient was a key of happiness and love proved to God. Patient becomes perfect when someone always receives whatever comes from God. ${ }^{29}$ This interdependency saw when God gives a different thing than what man wants. ${ }^{30}$

More than patient, thank to God also been something special for mystic expert, because it is not man's doing. By thank be to God, everyone told to understand something (it called hikmab) behind the fact or reality, even it is not enjoyable. ${ }^{31}$ Thus, spiritual force viewed as an outcome of experiencing spirituality through mystical practice should also influence decision of orientation.

\section{Batik Survivability in Culture, Myth and Commodity Perspectives}

For Javanese, batik cloth is a wealth symbol which showing traditional value. ${ }^{32}$ For long time ago, batik had not been a commercial thing. Only certain people who wear batik because the price was expensive and they were called brahmana and priest. Regarding this, astacandala community (ordinary people) is people who have the skill to prepare many things as ceremony tools. So, the motives of batik cloth grow as fast as need of religion ritual, and the design also change or adapt as fast as trust or religion. ${ }^{33}$

There are two manuscripts of mystical literature, Babad Tanah Jawi or Babat Meinsma and Serat Skondar which tell Nyi Roro Kidul and Den Ayu Lanjar are sisters. The two of the ocean authority has relation with

28 Ibid., p. 51.

${ }^{29}$ Schimmel, Mystical Dimension of Islam, p. 158.

${ }^{30}$ H. Horikoshi, A Traditional Leader in a Time of Change: The Kijaji and Ulama in West Java (Jakarta: P3M, 1976), p. 156.

31 Schimmel, Mystical Dimension of Islam, p. 160.

32 Sularso et.al., 60 Tabun Gabungan Koperasi Batik Indonesia (Jakarta: Gabungan Koperasi Batik Indonesia, 2009), p. 23.

33 I. Hanafi, Spiritualitas Batik Jlamprang Pekalongan (Pekalongan: P3M STAIN Pekalongan, 2011), p. 18. 
the design of batik cloth. If someone wants to communicate with those figures, such design as tool to know the existence of them. For example Nyi Roro Kidul or Ratu Kidul loved to the wirong or mirong design, and Den Ayu Lanjar loved to jlamprang design. Both of them as symbols of cosmology with their mystic of culture still exist for Javanese people.

Figure 3: Mode of Thought of Trust Achievement Trough Mystic Tradition

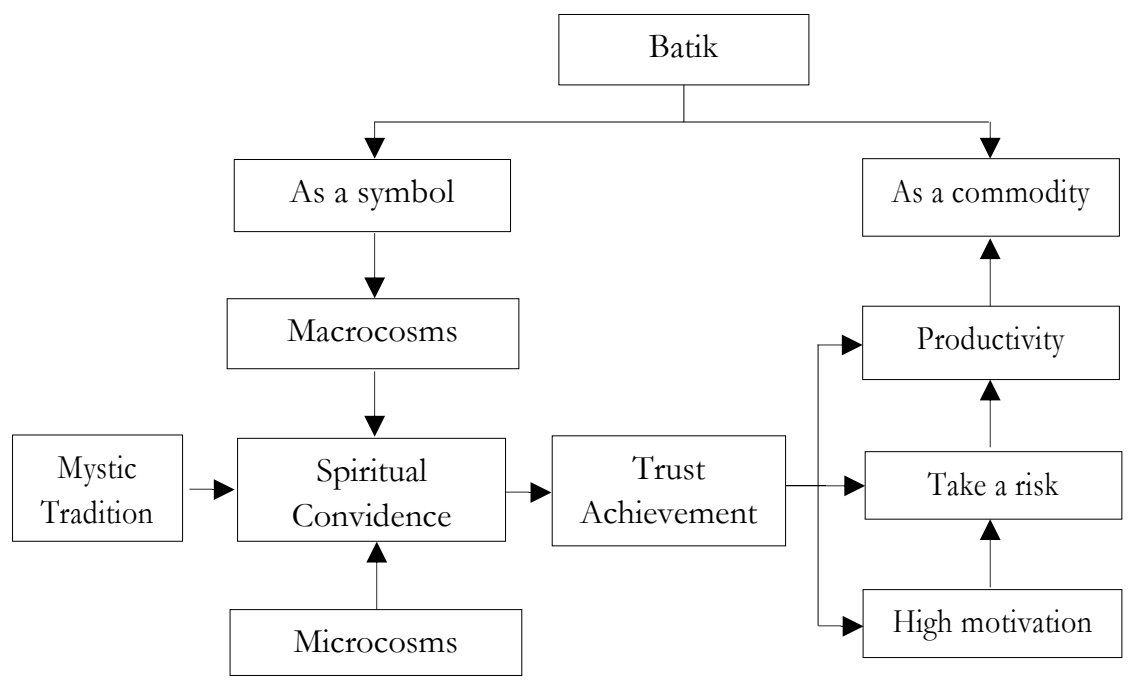

By mystical culture, batik is trusted as medium of expression to conduct human world to god and goddesses world, like Den Ayu Lanjar. The strength of batik as tool as expression medium is the holy thing, like what the King of Mataram done (with Parang Rusak and Sido Mukti design). ${ }^{34}$ For some people, batik also has a close relation with Nyadran tradition, which done by many fisherman on Shura (the name of Javanese month). Because of this, people know that batik is used as ritual tool, because batik had a magical meaning. More than these, batik still defense until this time at Pekalongan because of three main essential meaning: first, batik as goal target or hand down of

${ }^{34}$ Ibid., p. 56 
tradition, ${ }^{35}$ second batik as social practiced and third, batik as traditional craft man made. ${ }^{36}$

From figure 3 can be understood that the mystical tradition as a medium for the growth of spiritual consciousness which seeks to balance between macrocosm and microcosm, as well as on the role of symbols in batik. Spiritual awareness is further raises the trust. The trust was established to form a strong motivation that spawned person courage to take risks and foster productive attitudes. Mental series (motivation, risk and productivity) were born on the basis of trust, to be output from the mystical tradition of achievement of spiritual awareness conducted by both employer and employee within batik industrial relation.

\section{Conclusion}

In a business practice, of course include the batik industry at Pekalongan City an uncertainty condition always needs to be aware by the employer and employee. It's important to get mentality such calmness, patient and positive thinking to adapt it. The spiritual force which tries to make equality between spiritual and physical needy is very important not only for employer-employee in their relationship, but also to adapt the business change. At Pekalongan City, the people reached their spiritual force by many mysticism; dbikiran, manakiban, bawl and muludan. By those practices, they feel to be close to transcendent thing, that's God. Then their behavior be more patient, and they refer to entrust their business condition to Him beside they kept to try in their work.

Batik is well known because of culture context, myth and trading in Pekalongan City. Since Hindu era, Buddha and Islam, batik has an important role as spiritual tool. This capability of employer and employee influences for batik industrial maintenance, especially to face the uncertainty of business on local, regional, national or international scale.

This paper concludes that in spite of the business employeremployee hold can survive, they also improve their religiosity by joining many mystical practices. By using symbolic interactionism

\footnotetext{
${ }^{35}$ Sularso, 60 Tabun Gabungan Koperasi, p. 24.

36 Interview with Mr. Zahir, ex the Head of Museum of Batik Pekalongan (March 2012).
} 
perspective, it is clear that human behavior is as the product of myth, economy, culture, and belief. []

\section{Bibliography}

\section{Books and Articles}

Andrew, Mc W. "Some immaterial aspects of community economies in eastern Indonesia." The Australian Journal of Anthropology. 20, 2, (2009): pp. 163-177

Bjerke, B.V. "A Typified, Cultured Based, Interpretation of Management of SMEs in Southeast Asia." Asia Pacific Journal of Management. Vol. 17 (2000): pp. 103-132.

Blumer, Herbert. Symbolic Interactionism Perspective and Method. New Jersey: Printice-Hall, Inc., n.d.

Damami, M. Makna Agama Dalam Masyarakat Jawa. Yogyakarta: LESFI, 2002.

Eliade, M. Images and Symboles. Kansas City: Sheed Andrews and McMeel, Inc., 1952.

Endraswara, Suwardi. Mistik Kejawen; Sinkretisme, Simbolisme dan Sufisme dalam Budaya Spiritual Jawa. Yogjakarta: Narasi, 2006. . Falsafah Hidup Jawa. Yogyakarta: Cakrawala, 2010.

Fernando, M. et.al. "The Relationship Between Spiritual Well-Being and Ethical Orientations in Decision Making: An Empirical Study with Business Executives in Australia." Journal of Business Ethics, DOI 10.1007/s10551-009-0355-y (2010).

Hanafi, I. Spiritualitas Batik Jlamprang Pekalongan. Pekalongan: P3M STAIN Pekalongan, 2011.

Hasan, S. Sufism and the Spirit of Capitalism. Malang: UIN Malang Press, 2009.

Horikoshi, H. A Traditional Leader in a Time of Change: The Kijaji and Ulama in West Java. Jakarta: P3M, 1976.

Herusatoto, Budiono. Mitologi Jawa. Yogyakarta: Oncor Semesta Ilmu, 2011. 
Kaplan, S. and R. H. "Inertia and Incentives: Bridging Organizational Economics and Organizational Theory." Organization Science, Vol. 16 No. 5 (2005): pp. 509-521.

Meyer, J.W. and Rowan, B. "Institutionalized Organizations: Formal Structure as Myth \& Ceremony." The American Journal of Sociology. 83, 2 (1977): pp. 340-363.

Mulyati, S. Peran Edukasi Tarekat Qadiriyah Naqsyabandiyyah. Jakarta: Kencana Prenada Media Group, 2010.

Mufid, Ahmad Stafi'i. Tangklukan, Abangan dan Tarekat. Jakarta: Yayasan Obor Indonesia, 2006.

Needham, R. Belief, Languange and Experience. Oxford: Basil Blackwell \& Mott Ltd, 1972.

Niels, M. Kepribadian Jawa dan Pembangunan Nasional. Yogyakarta: Gadjah Mada University Press, 1996.

Romdon. Tashawnf dan Aliran Kebatinan: Suatu Perbandingan antara AspekAspek Mistik Islam dengan Aspek-Aspek Mistik Jawa. Yogyakarta: LESFI, 1995.

Schimmel, A. Mystical Dimension of Islam. trans. Sapardi Djoko et.al., Jakarta: Pustaka Firdaus, 1975.

Skorupski, John. Symbol and Theory. London: Cambridge University Press, n.d..

Subagya, R. Kepercayaan dan Agama. Yogyakarta: Kanisius, 1976.

Sularso et.al. 60 Tahun Gabungan Koperasi Batik Indonesia. Jakarta: Gabungan Koperasi Batik Indonesia, 2009.

Vallejo, M. C. "A Model to Study the Organizational Culture of The Family Firm." Small Business Economy, 36 (2011): pp. 47-64.

Wayne, T. The Mystic Heart: Discovering a Universal Spirituality in The World's Religions. Canada: Publishers Group West, 2001.

Widodo, S. K. Ikan Layang Terbang Menjulang, Perkembangan Pelabuban Pekalongan Menjadi Pelabuban Perikanan 1990-1990. Semarang: Badan Penerbit UNDIP \& Toyota Foundation, 2005.

Woodward, Mark R. Islam in Java: Normative and Mysticism. trans. Hairus Salim. Yogyakarta: LKiS, 1989. 